\title{
Communication
}

[Comunicação]

\section{Possibility of vertical transmission of caprine arthritis-encephalitis virus in neonate kids}

[Possibilidade de transmissão vertical do vírus da artrite-encefalite dos caprinos em cabritos]

\author{
M.C.C.S.H. Lara ${ }^{1}$, E.H. Birgel Junior ${ }^{2}$, E.H. Birgel ${ }^{2}$ \\ ${ }^{1}$ Instituto Biológico \\ Av. Conselheiro Rodrigues Alves, 1252 \\ 04014-002 - São Paulo, SP \\ ${ }^{2}$ Faculdade de Medicina Veterinária e Zootecnia - Universidade de São Paulo
}

Caprine arthritis-encephalitis (CAE) is characterized as an infectious, multisystemic disease, caused by a retrovirus of the Lentivirus genus, which infects caprines in several different ages, independent of gender, breed or production. The main clinical forms described in infected goats are: leukoencephalomyelitis, which mainly occurs in kids (Cork et al., 1974) and arthritis, more frequent in adult animals (Crawford et al., 1980).

Routes of transmission determining dissemination of the disease in herds have not been completely understood, but some researchers have reported the possibility of vertical transmission of the caprine arthritisencephalitis virus (CAEV) in kids during the pregnancy of infected goats. In most of the cases, though, transmission of the infection occurred preferentially in the post-natal period by the ingestion of colostrum and milk from infected goats (Crawford and Adams, 1981; Adams et al., 1983).

In order to assess the importance of the transmission of the CAEV by milk, Rowe et al. (1991), studied seronegative kids fed pasteurized and unpasteurized milk. The group of kids that was fed unpasteurized milk presented infection rates 3.3 times greater, as shown by seroconversion, than the group fed pasteurized milk. However, the infections caused by the virus in kids cannot be explained only by the ingestion of contaminated milk, because later on, the same group of researchers has shown that kids from seropositive dams presented seroconversion rates up to $10 \%$ at 6 months of age, even when fed pasteurized milk (Rowe et al., 1992). Because of that, perinatal infection has been considered to occur by the following routes: intra-uterine transmission during pregnancy, or transmission from the dam to the kid at the moment of birth due to the contact of the newborn with secretions from birth canal, as well as by accidental ingestion of colostrum and by the exposure of the kid to respiratory secretions and saliva from the dam, when it licks the offspring immediately after parturition (Adams et al., 1983).

In the evaluation of CAEV transmissibility, the vertical transmission of the virus was taken into account, that is, the transplacentary or uterine transmission at the parturition. However, this hypothesis was not irrefutably confirmed. Narayan and Cork (1990) reported that the transplacentary infection of the fetus by viremic blood from the dam does not seem to the most important route of dissemination of the disease in caprines.

The objective of the present trial was to study the ability of the caprine arthritis-encephalitis virus

Recebido para publicação em 1 de setembro de 2003

Recebido para publicação, após modificações, em 11 de fevereiro de 2004

E-mail: lara@biologico.sp.gov.br 
to infect the fetus or the neonate kid by the transplacentary route or at the moment of birth.

In order to evaluate the possibility and intensity of vertical transmission of CAEV in neonate kids - at the moment of parturition, 26 newborn kids were used. These kids were born in eutocic parturitions from infected goats, and raised in the Centro de Pesquisa e Diagnóstico de Enfermidades dos Ruminantes (CPDER) at the Departamento de Clínica Médica at Faculdade de Medicina Veterinária, Universidade de São Paulo. Blood samples were collected immediately after birth and before the ingestion of colostrum from positive goats and at 180 days of age in successive analysis of the presence of anti-CAEV antibodies.

Analysis of antibodies against CAEV was performed by agar gel immunodiffusion, according to Cutlip et al. (1977), using the glycoprotein (gp135) and protein antigens (p28), respectively, extracted from the envelope and the capside of CAEV (Caprine Arthritis-Encephalitis Antibody Test Kit, Veterinary Diagnostic Technology, Inc., USA). The test kit was used according to the instructions of the manufacturer.

In order to evaluate the possibility of vertical or transplacentary transmission of CAEV, the results of agar gel immunodiffusion in 26 neonates were considered. Blood serum was collected from these animals immediately after birth and before the ingestion of colostrum, and $100 \%(26 / 26)$ were negative for antibodies against CAEV. At 180 days of age, $100 \%$ of the kids did not present antibodies against caprine arthritis-encephalitis virus in blood.

To improve the knowledge on caprine arthritisencephalitis, considering its clinicalepidemiological aspects, this study on the vertical transmission of the virus during the parturition, either by transplacentary or perinatal routes, was performed. Findings in this trial are in agreement with the statement by Narayan and Cork (1990) that the transplacentary infection of the fetus during its intra-uterine development is of little significance, and should not be considered important in the dissemination of the disease. However, the present trial in not in agreement with the hypothesis by Adams et al. (1983), who attributed great epidemiological importance to the transplacentary or periparturition transmission of CAEV. According to these authors, in two kids supposedly infected by transplacentary route, seroconversion was observed in one of them at 4 months of age, and in the second at 32 months of age.

The results showed that none of the kids, born from goats infected by caprine arthritisencephalitis virus, was infected by vertical transmission of the virus. Therefore, it may be stated that the probability of infection by caprine arthritis-encephalitis virus by vertical route (transplacentary or during parturition) was less than $1: 26$, that is, lower than $3.8 \%$.

Keywords: caprine, caprine arthritis-encephalitis, virus, $\mathrm{CAEV}$, lentivirus, transmission

\section{RESUMO}

Estudou-se a capacidade do vírus da artrite-encefalite dos caprinos (CAEV) infectar o feto ou o cabrito neonato pela via de transmissão transplacentária ou no momento do parto. Foram utilizados 26 cabritos recém-nascidos, filhos de cabras sororreagentes aos antígenos do CAEV e que nasceram de partos eutócicos. Na pesquisa de anticorpos séricos anti-CAEV, foi utilizada a técnica de imunodifusão em gel de ágar. Nenhum cabrito nasceu sororreagente aos antígenos do vírus, indicando que a possibilidade de transmissão vertical transplacentária da infecção foi menor do que 3,8\% (<1:26).

Palavras-chave: caprino, artrite-encefalite dos caprinos, CAEV, lentivírus, transmissão 


\section{REFERENCES}

ADAMS, D.S.; KLEVJER-ANDERSON, P.; CARLSON, J.L. et al. Transmission and control of caprine arthritis-encephalitis virus. Am. J. Vet. Res., v.44, p.1670-1675, 1983.

CORK, L.C.; HADLOW, W.J.; CRAWFORD, T.B. et al. Infectious leukoencephalomyelitis of young goats. J. Infect. Dis., v.129, p.134-141, 1974.

CRAWFORD, T.B.; ADAMS, D.S. Caprine arthritisencephalitis: clinical features and presence of antibody in selected goat populations. J. Am. Vet. Med. Assoc., v.178, p.713-719, 1981.

CRAWFORD, T.B.; ADAMS, D.S.; CHEEVERS, W.P. et al. Chronic arthritis in goats caused by a retrovirus. Science., v.207, p.997-999, 1980.
CUTLIP, R.C.; JACKSON, T.A.; LAIRD, G.A. Immunodiffusion test for Ovine Progressive Pneumonia. Am. J. Vet. Res., v.38, p.1081-1084, 1977.

NARAYAN, O.; CORK, L.C. Caprine arthritisencephalitis virus. In: DINTER, Z.; MOREIN, B. (Eds.). Virus infections of ruminants. Amsterdam, Netherlands: Elsevier Science, 1990. p.441-452.

ROWE, J.D.; EAST, N.E.; FRANTI, C.E. et al. Risk factors associated with the incidence of seroconversion to caprine arthritis-encephalitis virus in goats on California dairies. Am. J. Vet. Res., v.53, p.2396-2403, 1991.

ROWE, J.D.; EAST, N.E.; THURMOND, M.C. et al. Cohort study of natural transmission and two methods for control of caprine arthritis-encephalitis virus infection in goats on a California dairy. Am. J. Vet. Res., v.53, p.2386-2395, 1992. 